\title{
Memória, história e tradição: um diálogo entre o velho e o novo no romance Lueji, o nascimento de um império
}

\author{
Memory, history and tradition: a dialogue between the old and the \\ new novel Lueji, o nascimento de um império
}

\author{
FÁbio HenRique Novais de MESQuita ${ }^{1}$ \\ MÁrCia MANir Miguel Feitosa ${ }^{1}$ \\ ${ }^{1}$ Universidade Federal do Maranhão. São Luís, MA, Brasil.
}

\begin{abstract}
Resumo: As literaturas africanas em língua portuguesa despontam com muita força no século XX e, aos poucos, ganham espaço na contemporaneidade por meio de narrativas que problematizam a escrita da história a partir de epistemologias eurocêntricas. Nosso objetivo é analisar o romance Lueji, o nascimento de um império (1990), de Pepetela, a partir de olhares que nos ajudem a compreender de que forma a memória, a história e a tradição se entrelaçam em espaços-tempos diferentes e como as ações do presente se constituem por meio de uma reatualização da memória sem a pretensão de veracidade da história oficial. A tradição se constitui então como o elo entre o passado, a memória, e o futuro, reinvenção contínua do presente. As personagens centrais, Lu e Lueji, participam de realidades que questionam a força das tradições, dependendo das suas interpretações para validá-las ou não, cada uma em seus contextos.
\end{abstract}

Palavras-chave: Lueji; Angola; Literatura Africana lusófona; Memória; História.

\begin{abstract}
The African literatures in the Portuguese language appear and rise, strongly, in the $20^{\text {th }}$ century and, slowly, get their space in the contemporaneity through the narratives which used to question the historical written based on the Eurocentric epistemology. Our goal is analyze the novel Lueji, o nascimento em um império (1990), by Pepetela, through points of view that help us to comprehend the way memory, story and tradition intertwine on different space-times and how the present actions are made by the memory upgrade without the needing of the legitimate story veracity. The tradition, therefore, was made as a bound between the past, memory and the future, a continuous present remake. The main characters, Lu and Lueji, participate on realities that question the traditions strength, depending on their interpretations to validate or no, each one in their own context.
\end{abstract}

Keywords: Lueji; Angola; Lusophone African literature; Memory; History.

\section{Introdução}

Os países africanos lusófonos viram, a partir da segunda metade do século XX, o alvorecer do sonho da liberdade nascer e morrer ao mesmo tempo. A independência conquistada com muita luta cedeu lugar à disputa de poder entre os vários grupos étnico-políticos existentes e a guerra civil passou a ser uma realidade eminente.

As rupturas causadas por uma história em permanente conflito entre o factual e o contingente recolocam as literaturas produzidas na África no cenário de reflexões sobre a História e a Memória Coletiva, numa disputa entre a Tradição e a Modernidade. A literatura produzida neste continente se impõe como forma de combate a estereótipos forjados no seio da colonização e que exigem um trabalho intenso para a desconstrução do discurso histórico construído em bases epistemológicas eurocêntricas, ajudando a elaborar a imagem de um continente fetichizado pela indústria do turismo.

Com isto, a importância de trabalhos que busquem compreender a África a partir de realidades que se diferem pelos percursos históricos, ao mesmo tempo em que se aproximam pela capacidade de se reinventar, torna-se fulcral para identificar as várias formas de fazer literário como o moçambicano, o cabo-verdiano e o angolano e suas 
características próprias. A África, como todo continente, abarca realidades e histórias diferentes que merecem um olhar que busque particularidades que orientem para uma percepção mais coerente de seu percurso. Encarar tais trajetórias como lineares é contribuir para a negação das histórias que se levantam em cada um dos países que viveram como colônia, mas buscam seguir rumos diferentes na sua constituição identitária.

Dentre os mundos plurais encontrados em África, está Angola que, de acordo com Feitosa (2016), se ergue num movimento de resistência cultural, encontrando na escrita literária um meio de escuta e uma arma contra qualquer forma de opressão. Os escritores se empenham em não deixar morrer o sonho utópico da liberdade e buscam no passado uma forma de reestabelecer as estruturas rompidas pelo colonialismo.

Neste percurso, "Pepetela não hesita em seguir variados caminhos: recorre a mitos, vai às fontes da História, subverte-as; reinventa o passado; e critica, satírica ou acidamente, o presente" (CHAVES, 2005, p. 87). Ele empresta seu olhar de sociólogo e historiador, aliado à sua experiência e vivência direta nos conflitos instaurados pelo colonialismo e acentuados pela guerra civil, para desvelar as sendas escondidas pelos interstícios da Ciência Historiográfica que, por meio de sua narrativa, impôs o silêncio e fez acreditar no esquecimento.

O labor impresso em escritas literárias como a de Pepetela evidencia acontecimentos protagonizados pela memória sem a pretensão da verdade. Seu trabalho se dá por meio do resgate de fontes orais, como o mito, numa tentativa de contestar a univocalidade histórica e dialogar com vozes que até então não tinham relevância verídica e factual. A interlocução entre a Tradição e a Modernidade é um aspecto que merece destaque na análise, pois, no romance, a validade da Tradição, assim como suas consequências, são colocadas à prova tanto no reino de Lunda quanto na moderna Luanda.

\section{A história vivida: a experiência da memória}

Para tentar compreender a memória, ao mesmo tempo, como método e objeto de estudo deste artigo, faremos um recorte teórico sobre este fenômeno construído (cf. POLLAK, 1992). Antes que se percam de vista estes dois termos assinalados por ele, vale ressaltar que as perspectivas metodológicas lançadas sobre este "objeto" têm reforçado o quanto se faz necessária uma abordagem interdisciplinar, na tentativa de compreender o fenômeno da memória na dinâmica social e suas contribuições para outras possiblidades de reescrita de histórias.

É indispensável, para qualquer estudo acerca deste fenômeno, estabelecer o diálogo com Maurice Halbwachs e sua teoria social da memória coletiva, pois, a partir de sua pesquisa, surgiram e continuam surgindo prolongamentos que reelaboram suas teorias num trabalho de reatualização de seu pensamento. O pressuposto de que a memória é um fenômeno construído apenas em sociedade e não tem chances de se constituir fora deste espaço/tempo o conduz a um rompimento com os estudos de sua época em que a memória era "compreendida primordialmente enquanto fenômeno individual e subjetivo" (SEPÚLVEDA, 2003, p.35).

Filiando-se a Durkheim, Halbwachs começa uma investigação de caráter empírico para verificar de que forma os grupos sociais com os quais o indivíduo mantém contato em determinado tempo e espaço determinam a reorganização das lembranças. A teoria da memória coletiva para este sociólogo nos ajuda a compreender que "tudo o que nós lembramos do passado faz parte de construções sociais que são realizadas no presente" (SEPÚLVEDA, 2003, p.35). Apesar das experiências vividas dentro do grupo e da forma como elas são captadas por cada um - como indivíduo e como coletividade -, sua pesquisa se direciona para uma compreensão dedutiva da elaboração da memória. Na obra $A$ memória coletiva (2003), ele reforça a perspectiva de que a alteridade é fundamental dentro de sua proposta teórico-metodológica.

Nesta perspectiva, enfatiza que o testemunho do outro pode tanto concordar quanto discordar dos nossos, assim como ajudar a reconstruir as lembranças em espaços/tempos que ora se distanciam, ora se aproximam, de acordo com o nível de envolvimento afetivo partilhado em uma rede de solidariedades. Os testemunhos podem agir de três formas: reforçando, enfraquecendo ou completando espaços obscuros relativos a eventos que vivemos simultaneamente com outros:

Claro, se a nossa impressão pode se basear não apenas na nossa lembrança, mas também na de outros, nossa confiança na exatidão de nossa recordação será maior, como se uma mesma experiência fosse recomeçada não apenas pela mesma pessoa, mas muitas (HALBWACHS, 2003, p. 29).

Os grupos sociais funcionam como pontos de apoio para nossas recordações e nos colocam no centro da dialética memória e identidade, como nos propõe Michael Pollak (1989). Segundo ele, Halbwachs enfatizou apenas a força agregadora da memória e seu papel na manutenção da estabilidade do grupo e da coesão social. Pollak propõe, contudo, uma inversão teórico-metodológica no rumo das pesquisas ao acentuar o caráter coercitivo que age sobre a memória coletiva. Ao deslocar o olhar da constituição do fato social como coisa e em detrimento de uma visão estruturalista-funcionalista, valoriza-se o processo pelo qual os atores sociais agem sobre a sociedade, não mais passivamente, mas de uma perspectiva construtivista. 
Cabe agora saber como essas coisas se tornam fatos sociais. Reivindicando o não esquecimento, numa tentativa de saltar do anonimato para a publicidade, tais memórias esperam a circunstância adequada para romper o silêncio. Sentindo-se ameaçadas pelo esquecimento, elas ganham voz e travam uma luta na tentativa de se tornarem críveis, admissíveis e aceitáveis para que haja o seu enquadramento (cf. POLLAK, 1992). Neste processo, vai ser dada ênfase, assim como em Halbwachs, à importância da testemunha, e a memória vai trabalhar num processo seletivo de lembranças que mais concordam do que discordam.

Paul Ricouer (2007) aproxima seu trabalho aos de Halbwachs e Pollak ao valorizar o testemunho como condição de uma memória crível, aceita e admissível. Valendo-se do método hermenêutico-fenomenológico, arrisca empreender um Esboço fenomenológico da memória, na busca pela sustentação para sua tese: a memória é do passado, pois está convicto de que não temos outra via para referenciar o passado, senão a própria memória (cf. RICOUER, 2007). Os argumentos que alicerçam sua afirmação passam pelos trabalhos de Aristóteles, Agostinho de Hipona e Bergson para os quais a recordação se coloca entre a espontaneidade e a busca, cujo tempo é o "fio condutor". Ao se colocar na esteira do pensamento aristotélico, conduz método comparatista conforme o método análogo do filósofo grego. Ou seja, entre a

simples homonímia remetida à dispersão do sentido, e a polissemia, estruturada por um núcleo sêmico que seria identificado por uma verdadeira redução semiótica. (...) A razão da relativa indeterminação no estatuto epistemológico da classificação proposta aparece na imbricação entre a experiência pré-verbal - que chamo de experiência viva, que traduz o Erlebnis da fenomenologia husserliana - e o trabalho de linguagem que põe inelutavelmente a fenomenologia no caminho da interpretação e, portanto, da hermenêutica [grifo do autor] (RICOUER, 2007, p. 43).

Com isso, justifica que uma proposta que requer o olhar fenomenológico como apoio constitui-se de fragmentos que não estão em total dispersão. Ao falar de esquecimento, este trabalho concorda com o entendimento de Paul Ricouer (2007) sobre este processo, para o qual o filósofo francês propõe uma compreensão diferente daquela de apagamento/dispersão total das lembranças, da memória. O esquecimento é mais um obstáculo para o acesso ao conteúdo das lembranças do que o seu desaparecimento completo.

(...) como falar do esquecimento senão sob o signo da lembrança do esquecimento, tal como o autorizam e caucionam o retorno e o conhecimento da "coisa" esquecida? Senão, não saberíamos que esquecemos. Um enigma, porque não sabemos, de saber fenomenológico, se o esquecimento é apenas impedimento para evocar e para encontrar o "tempo perdido", ou se resulta do inelutável desgaste, "pelo" tempo, dos traços que em nós deixaram, sob forma de afecções originárias, os acontecimentos supervenientes [grifos do autor] (RICOUER, 2007, p. 48).

A relação entre a memória e a História, esta enquanto um saber institucionalizado e uma pretenciosa visão unívoca do passado, e aquela história vivida pode ser compreendida pela dialética da aproximação e distanciamento espaço/temporal: História distante e memória próxima ao espaço/tempo do vivido, portanto fenomenológico. Enquanto uma se interessa por um passado fossilizado, pois arrancado do seu espaço/ tempo, a outra se atém a um passado dinamizado pelas percepções presentes, cujas categorias espaço/tempo têm a durabilidade do fenômeno quando ainda é percebido. Contudo, Pierre Nora (1993, p.7) chama a atenção para uma possível morte da memória promovida pela "aceleração da história".

Esse movimento proporcionou a criação de lugares de memória que nada mais são, de acordo com ele, do que rastros e vestígios de um passado que não tem mais como se adequar às necessidades do presente. De acordo com Nora, a ambição de veracidade da História é marcada pela sua preferência por fatos temporalizados, desenraizados dos contextos em que se dessacralizou a memória. A concordância entre ele e Halbwachs se efetiva quando ambos tomam o aspecto coletivo da memória como história vivida, e a História, que se pretende à pureza empírica, como uma mera operação intelectual, arquivista (NORA, 1993). A reconstituição realizada pela historiografia se dá por meio de um criticismo que se empenha em destruir a vivacidade da memória:

Menos a memória é vivida no interior, mais ela tem necessidade de suportes exteriores e de referências tangíveis de uma existência que só vive através delas. (...) O sentimento de um desaparecimento rápido e definitivo combina-se à preocupação com o exato significado do presente e com a incerteza do futuro para dar ao mais modesto dos vestígios, ao mais humilde testemunho a dignidade virtual do memorável (NORA, 1993, p. 14).

O momento do "desaparecimento" da memória tradicional obriga a uma acumulação de rastros, de vestígios que possam sinalizar para o que deixou de existir como continuação de uma experiência vivida. Para que haja memória, é necessário que haja uma ritualização, uma repetição de costumes, do vivo das tradições no interior de um grupo, de uma sociedade. 
Assim como Nora, para a cientista social Myrian Sepúlveda dos Santos (2003), o "mundo moderno" põe em perigo a tradição, promovendo a ruptura total entre passado e presente. Para ela, a memória é um dos valores mais caros ao ser humano. Defender a justiça e a liberdade é um trabalho motivado pela necessidade de sua preservação (SANTOS, 2003). Na modernidade, onde o que está em voga é o imediatismo do presente, percebe-se o comprometimento da ação consciente do sujeito sobre sua história, na medida em que os novos paradigmas instaurados, como a individualização, tendem a tornar mecânicas as ações humanas.

Acentua-se a preocupação com a perda da memória e as várias áreas do conhecimento voltam sua atenção para ela. A literatura, como locus privilegiado da interdisciplinaridade, se incorpora à luta contra o nãoesquecimento, como um lugar de memória, não no sentido de Nora, para quem estes lugares não possuem a aura do vivido. Mas no empreendimento de libertação de memórias "clandestinas" e "proibidas", na emergência tanto no sentido de urgência quanto de (re)aparecimento - de um passado que continuamente se transforma pelas ações conscientes do e no presente.

$\mathrm{Na}$ sessão seguinte, percorreremos a literatura africana lusófona produzida em Angola pelo olhar de Artur Carlos Maurício Pestana dos Santos, mais conhecido como Pepetela, no romance Lueji, o nascimento de um império (2015), em direções que apontam para: (1) a ruptura com uma visão da história oficial como a única possibilidade de "memória", portanto ideológica e excludente em sua natureza; (2) a memória como o passado vivido, e não como uma simples tentativa de representação do passado; (3) o resgate da tradição oral e de sua transmissão - palco, por privilégio, da memória e onde os protagonistas são os velhos - como guardiães e veículos, respectivamente, de saberes que constituem o legado cultural, uma tentativa de validar a tradição, não como uma amarra ao passado, mas como um ponto de partida para mudanças; (4) a valorização da pluralidade cultural, assim como a memória também o é, no intuito de afirmar essa condição nas próprias vivências cotidianas.

\section{Lueji, o nascimento de um império: entre Lunda e Luanda no espaço/tempo da memória}

Mais no plano da ratificação do que da justificação, vale ressaltar a importância do percurso realizado anteriormente para se chegar até aqui. Outros aspectos terão mesma relevância, pois participam, de maneira simultânea e indiscutível, no trabalho da memória, como a tradição - circulação interna de saberes múltiplos por meio de gestos ritualizados e repetidos no cotidiano - e a língua, cujo exercício consciente e efetivo nas práticas sociais garante o direito à comunicabilidade $\mathrm{e}$, consequentemente, ao acesso cultural na perspectiva de uma ascensão social em um mundo com lugares já demarcados.

Pires Laranjeira, crítico literário e um dos mais profícuos estudiosos da Literatura Africana em língua portuguesa, em sua obra Literatura Calibanesca (1985, p. 10), afirma que é "Literatura africana: porque África é o motivo da sua mensagem ao mundo, porque os processos técnicos da sua escrita se erguem contra os modismos europeus ou europeizantes". Torna-se imprescindível para os países deste continente lograr seu lugar no mundo reivindicando suas histórias soterradas pelos longos anos de dominação europeia. Começa então um árduo trabalho de indivíduos engajados na luta pela libertação não só territorial, mas também política, cultural, social e econômica e que optam pela criação literária como

busca do direito à diferença e constituiu-se enquanto desejo de emancipação colectiva, renúncia impossível à aculturação inexorável (como via libertadora), denúncia de explorações e repressões e, finalmente, grito de vitória política (LARANJEIRA, 1985, p.7).

Neste itinerário, a literatura angolana se impõe como força que engendra, por meio da memória, uma via de reapropriação da cultura renegada pelo poder do colonizador. Percebe-se uma grande preocupação e compromisso dos escritores em contar a história renegada pela própria História, desvelando o que a colonização escondeu, fazendo vir abaixo estruturas opressoras que condenaram seu passado ao esquecimento.

O projeto de construção de uma nação se torna pano de fundo para a criação literária que tem sua efervescência entre 1961 e 1971. A principal causa deste alvorecer literário é a guerra anticolonial que estoura em Angola neste mesmo período e já mostra a evidente relação entre a produção literária e os movimentos políticos de contestação do colonialismo. Momento propício para o surgimento da União dos Escritores Angolanos - UEA -, fundada em 10 de dezembro de 1975, um mês após a tão sonhada independência. Há uma relação estreita entre a literatura e o que se pensa sobre nação em Angola.

A preocupação em mostrar uma cultura nacional que se expressa em língua portuguesa traz consigo um cuidado em pensar “quem é Angola?" por meio de sua própria realidade, seu próprio estilo, sua própria literatura. Os escritores ligados à UEA eram ao mesmo tempo membros ou simpatizantes do Movimento Popular pela Libertação de Angola - MPLA -, do qual participavam autores como Pepetela que emprestaram sua bravura e talento não só no campo da guerrilha, mas também no literário.

Este universo literário, que se funde ao político por meio de seus atores que, engajados na causa da 
independência e imbuídos pelo espírito de afirmação de uma identidade própria/nacional, se torna mediador entre a percepção do MPLA em relação ao país e à criação de uma memória coletiva que a Literatura produzia em Angola. Desempenhando um papel político muito importante no processo de institucionalização da Literatura no país, Pepetela ganha destaque por ser um dos que mais produziram obras neste período. Além do destaque pelo conteúdo temático de sua obra, "ele é o único nome quase que exclusivamente identificado com o romance como forma de expressão" (CHAVES, 2005, p. 86)

Publicado em 1990, Lueji, o nascimento de um império, coloca em discussão a validade das tradições em dois espaços/tempos que se distanciam do ponto de vista cronológico, mas se aproximam fenomenologicamente, uma vez que tal percepção [do tempo] "é, antes, a medida do movimento do que o próprio movimento" não se reportando à regularidade do "movimento dos corpos celestes (...), mas na medida de movimento da alma humana. O movimento pode parar, o tempo não" (RICOUER, 1994, p.33). O primeiro capítulo do romance a ser analisado se divide em duas partes: Quatro séculos atrás (pelo menos)... - Quatro séculos depois (amanhã)... onde vivem as personagens centrais Lueji e $\mathrm{Lu}$, respectivamente.

Para tentarmos compreender o investimento que as narrativas pós-coloniais fazem no passado, estudos como os de Edward Said corroboram para o empreendimento da memória, visto que "a invocação do passado constitui uma das estratégias mais comuns nas interpretações do presente" (SAID, 2011, p. 34) e reforça, de acordo com as ideias de T.S. Eliot, que a "maneira como formulamos ou representamos o passado molda nossa compreensão e nossas concepções do presente" (SAID, 2011, p. 36).

Na esteira desta reflexão, percebemos que o passado como tema é lugar deveras revisitado e reinventado pelos autores angolanos. As subseções que se seguem terão o mesmo título desta subdivisão para percebermos que, mesmo em contextos diferentes,

confiando à memória o destino das coisas passadas e à espera das coisas futuras, pode-se incluir memória $\mathrm{e}$ espera num presente ampliado e dialetizado que não é nenhum dos termos anteriormente rejeitados: nem o passado, nem o futuro, nem o presente pontual, nem mesmo a passagem da espera (RICOUER, 1993, p. 28).

São duas realidades que, compreendidas na narratividade ficcional, percorrem entre as aporias do tempo e da memória, sendo admitidas como passado, presente e futuro, num contínuo movimento dialético. Entram em cena a tradição e sua força reflexiva do renovar-se, num círculo hermenêutico em que o velho e o novo são referências da passagem do presente, da extensão do tempo na alma:

É à memória que está vinculado o sentido de orientação na passagem do tempo; orientação em mão dupla, do passado para o futuro, de trás para a frente, por assim dizer, segundo a flecha do tempo da mudança, mas também do futuro para o passado, segundo o movimento inverso de trânsito da expectativa à lembrança, através do presente vivo (RICOUER, 2007, p. 108).

O que fomenta esta investida da memória não é somente a contestação sobre a veracidade do que passou, mas compreender como este passado se faz presente, tendo em vista as marcas que ele imprimiu no tempo (cf. SAID, 2011).

Esta distinção entre os dois contínuos espaço/ tempo é reforçada apenas no primeiro capítulo para marcar o ponto de partida para uma discussão entre a tradição e a modernidade, as memórias (história vivida) e a história (sepultura da memória). Mantê-la-emos na análise apenas para salientar particularidades existentes nos dois contextos, contudo unidas pelo mesmo desejo: a necessidade de experienciar Angola como lugar "quando este adquire um significado mais profundo e mais íntimo" (OLIVEIRA, 2012, p. 12). Esta reflexão é expressa pelas personagens Lueji e Lu no romance de Pepetela, na medida em que as "imagens do passado e do futuro são imagens do presente continuamente recriados." (OLIVEIRA, 2012, p. 13).

\subsection{Quatro séculos atrás (pelo menos)... A Lunda da rainha Lueji}

Lunda é um reino alicerçado na tradição dos ancestrais para fins de preservação de valores que contribuem para manter a coesão do grupo. Neste contexto, convivem, dentre tantos outros personagens, Lueji, seus irmãos, Tchinguri e Chyniama; seu pai, o soba Kondi; Kandala, o adivinho. A grande preocupação de Kondi é a sua sucessão. Sob a ameaça do rompimento com a tradição que lhe rondava a alma, e como nenhum dos seus filhos homens se mostrava preparado para substituí-lo, Kondi vai ao encontro de Kandala (cf. PEPETELA, 2015), pois temia pelo destino do reino caso Tchinguri o sucedesse, visto que este sempre demonstrara desrespeito pela tradição:

- A tradição se torce quando é preciso - disse Chyniama.

- A tradição depende da força - reforçou Nandonge.

- E quem tem a força? Perguntou Lueji.

- Kondi - disse Tchinguri. - Ele tem o lukano (PEPETELA, 2015, p. 17). 
A atitude do soba não é bem recebida pelo filho mais velho. Após ser violentamente espancado por seu primogênito Tchinguri e seu irmão Chyniama, a decisão de Kondi se efetiva, passando a responsabilidade do reino para a filha, contrariando uma tradição ao indicar uma mulher para a sua sucessão, para a garantia de outra: manter o poder dentro de sua linhagem, dentro de sua família.

Lueji é nomeada - mesmo contra a vontade rainha pelo pai, o soba Kondi, de quem recebe o lukano, símbolo do poder maior na comunidade. Contudo, tem que se submeter à tradição, com instruções de Kandala, pois foi salvaguardada pela sua palavra decisiva, "figura veneranda do mais velho entre os velhos, chamado para ditar o destino do soba grande dos Tubungo" (PEPETELA, 2015, p. 20).

A valorização da figura do mais velho é visceral para a cultura africana, sendo ele o repositório de uma sabedoria ancestral que mantém, ao mesmo tempo, proximidade "dos homens, dos deuses e do ser supremo, cujas linguagens dominam" (PADILHA, 1995, p.10). Tendo em vista que a cultura autóctone encontra suas bases na oralidade, observamos que

Quando nos referimos à questão do conhecimento e sua transmissão a partir da oralidade, estamos nos marcos de uma fórmula de acumular e transmitir os conhecimentos sobre a história e os ensinamentos do cotidiano de uma comunidade, que tem como palco privilegiado a memória e como protagonista os mais velhos (CHAVES; MACÊDO, 2007, p. 15).

A memória coletiva assume a função de agregar e manter a coesão do grupo. Eram, na reunião do conselho, tomadas todas as decisões mais importantes que ditam os caminhos do grupo; o conselho dos mais velhos reuniu-se para discutir o destino da comunidade, a eleição do novo líder a partir da indicação de Kondi. Entre muitas discordâncias que refletiam a disputa pelo poder, mais uma vez a sabedoria do mais velho entre eles, o Kandala, é respeitada e indiscutível. Ao tomar a palavra,

Kandala só falava uma vez e era a última, Lueji será a nossa soberana e escolherá o marido que a ajudará a governar, até o neto de Kondi ter razão suficiente para tomar o lukano, assim está escrito no meu ngombo, único ngombo da Lunda que pode adivinhar o futuro, pois os outros só advinham o que passou e suas causas, mas quem quiser desafiar a escrita do ngombo que o faça mas não se queixe depois se sua família desaparecer numa noite, pois nada posso fazer contra os malefícios em que incorrem os descrentes (PEPETELA, 2015, p. 25).
A ordem se institui por meio da palavra tomada pela fala do mais velho, se tornando assim um ato performativo, pois

Uma sociedade oral reconhece a fala não apenas como um meio de comunicação diária mas também como meio de preservação da sabedoria dos ancestrais, venerada no que poderíamos chamar de elocuçõeschave, isto é, a tradição oral. A tradição pode ser definida, de fato, como um testemunho transmitido verbalmente de uma geração para outra. Quase em toda parte, a palavra tem um poder misterioso, pois palavras criam coisas. Isso, pelo menos, é o que permanece na maioria das civilizações africanas (...) (VANSINA apud CHAVES; MACÊDO, 2007, p. 16).

A experiência deste romance, assim como de outros do mesmo cunho, nos coloca defronte de uma expressão literária que tem reivindicado autonomia tanto pelo trato estético dos autores, quanto pela tentativa de recolocar o processo de formação identitária da África no mesmo contexto político, social, econômico e cultural do mundo globalizado. O ponto de vista do colonizador é contraposto por um ponto de vista angolano, dando vozes a atores sociais que talvez tenham sido testemunhas de fatos narrados pela história e que, de seus lugares, manifestam suas vozes silenciadas pelos registros coloniais.

Este fato é percebido no romance em análise pela presença de um narrador onisciente, numa ininterrupta fusão entre o passado e o presente. Outras vozes aparecem reclamando suas versões sobre a história. As vozes cerceadas emergem com opiniões e pontos de vista a partir do contexto em que estão envolvidas. Assim, o primeiro a se manifestar é Kondi, pai de Lueji, que de início mostra sua preocupação em dar o lukano para o filho mais velho Tchinguri, receoso de que este não seguisse as tradições lundas para se entregar às diferentes versões da história, ao "falar", postumamente, "que seria dos homens se adivinhassem tudo pode ser contado de mil maneiras diferentes e sempre verdadeiras?" (PEPETELA, 2015, p. 26).

O poder simbólico atribuído à palavra é reforçado como sua expressão e efetivação por meio da afeição, em uns, ou pela coerção, em outros. Para Laura Cavalcante Padilha,

Os ritos iniciatários - eles próprios uma face do processo sócio-histórico mais abrangente - também tem na oralidade a base de sustentação, embora não se possa descartar o seu aspecto mágico, por sua vez uma forma simbólica de trabalhar, no plano da cultura, os segredos e os mitos fundadores (PADILHA, 1995, p. 16).

O espaço do conselho, onde a comunidade se reúne, é, para além das tomadas de decisões importantes, também 
um espaço de contação de estórias populares, um espaço de aprendizado sobre a história de seu povo, as cantigas, com a memória apoiada no grupo social do qual se sente pertencente,

cujos conhecimentos transmitem-se de forma oral, instauram no ensino, na conservação e na veiculação dos seus valores, através das gerações. Assim, as narrativas tornar-se-iam, simultaneamente, atos de cultura e instrumentos de transmissão de conhecimentos (CHAVES; MACÊDO, 2007, p. 16).

Corroboram com esta ideia as palavras de Márcia Manir Miguel Feitosa, para quem

\begin{abstract}
Dada a condição de território eminentemente não letrado, Angola conquistou pela recepção coletiva o espaço de libertação da oralidade, permitindo que a cultura simbólica ganhasse voz e se expandisse como prática ritualística. Assim, tornou-se mais expressiva para o angolano a detenção da palavra falada, símbolo de luz e autoridade (FEITOSA, 2016, p. 66).
\end{abstract}

A Kandala, o grande adivinho, o mais velho dentre os velhos, coube a função de ensinar Lueji, mostrando que o conhecimento do passado é uma via de aprendizado. Ele assume a função de transmissor do conhecimento que lhe é conferido pela sua condição de ancião, tomando a postura de griot:

o papel dos velhos é fundamental nesse processo de reelaboração simbólica, pois tanto são eles, via de regra, os guardiães contadores de histórias, como são ainda os condutores das cerimônias pelas quais os neófitos ingressam nos mistérios do novo mundo, cujas portas lhes são abertas pela iniciação (PADILHA, 1995, p. 21).

Por meio da memória e da afirmação de que ela é a nossa única via de acesso ao passado (cf. RICOUER, 2007), percebe-se que a voz ancestral é esta ligação entre o mundo dos "mortos", o passado, e o mundo dos "vivos", o presente, num eterno devir. Para este adivinho, o líder é aquele que tem o dever de agregar as memórias e fazer da concordância entre elas um reflexo da vontade de todos, em detrimento de visões particulares. Mesmo contra sua vontade, Lueji submeteu-se ao seu rito de entronização, que acontecia simultaneamente à cerimônia do enterro de Kondi. Este evento é marcado pela postura de Lueji que modifica o ritual, suprimindo alguns elementos da tradição, enquanto o funeral de Kondi obedecia a todos os protocolos tradicionais. $\mathrm{O}$ velho e o novo incorporam-se ao mesmo tempo na realidade de Lunda de formas diferentes: Lueji como a nova rainha e Kondi como um antepassado, um ancestral.

\subsection{Quatro séculos depois (amanhã)... A Luanda da bailarina Lu}

$\mathrm{Lu}$, uma bailarina angustiada com a repetição dos modelos europeus que mascaram a riqueza cultural de Angola, busca na história/mito de Lueji elementos que possam, por um processo de identificação, reavivar a memória coletiva luandense para a reapropriação de uma identidade perdida. Separadas pelo tempo e pelo espaço de mais ou menos quatrocentos anos, as suas histórias se entrecruzam entre o passado mítico do povo lunda, governado pela rainha Lueji, e um presente narrativo que remonta ao fim do milênio.

Neste momento, o sentimento de Lu é traduzido pela voz do narrador que representa a memória coletiva, onde tentam coexistir na modernidade duas culturas e percepções do presente distintas: a europeia e a local que se distanciavam, principalmente, na maneira de conceber a história e, consequentemente, a realidade circundante neste fim e começo de milênio em que se contrapunham os mitos de guerra e destruição ocidentais aos locais, de nascimento e formação. $\mathrm{O}$ narrador onisciente, além de testemunhar os fatos, revela os sentimentos que afetam a Luanda moderna e seus atores sociais:

Faltavam poucos meses para a mudança do século. Os velhos mitos renasciam com a aproximação do ano 2000. Medos. Esperanças. Arritmias. Fim do mundo, julgamento final? Bem, procurávamos nos afastar desses temores, pensando isso são mitos da Europa, lendas criadas a partir dos semitas e do novo testamento, que temos nós, bantos, a ver com isso, os nossos mitos são outros, de nascimento e formação, não de mortes e catástrofes escritas em livros antigos. Mas o mundo deixara de ser o somatório de mundos fechados, era um só, cada vez mais mestiços (PEPETELA, 2015, p. 28).

Percebe-se a força do testemunho do outro, assumido pelo narrador neste contexto, para afirmar a credibilidade das lembranças. Contudo, apenas o testemunho dos atores sociais, a quem a história renegou a voz, não é suficiente, e, para desmascarar os falsos testemunhos, Lu terá que opor "aos testemunhos tachados de suspeitos outros reputados mais confiáveis. (...) o testemunho constitui a estrutura fundamental de transição entre a memória e a história" (RICOUER, 2007, p.41).

Empenhada na montagem de um bailado para o grupo de Dança Kukina, do qual fazia parte, mergulhou num intenso trabalho de pesquisa recorrendo a diversas fontes escritas e orais para reconstruir o passado mítico de Lunda. Juntamente com suas pesquisas no Centro de Documentação que lhe davam embasamento histórico a respeito da Lunda, Lu trazia consigo, em sua lembrança, estórias sobre Lunda que escutara de sua vó que vivia em Benguela, onde Lu havia passado a infância: 
Ouvia música indefinível de marimbas, procurava algo desconhecido em livros sobre a Lunda, só porque a avó viera de lá para Benguela e encheu a infância dela de lendas e estórias de feitiço, cuidado menina, teu pai não acredita porque é branco, mas eu vi muita coisa, vivi muito, sabedoria antiga, não despreza só (PEPETELA, 2015, p. 28).

Isto nos remete à crítica de Halbwalchs (2003) à concepção da memória como uma tabula rasa ao afirmar que, pelo esforço da recordação, alguns "contornos" são trazidos pela imagem do passado. Apesar de não conseguir reconhecer os sons que lhe vinham à cabeça, eles estavam lá, como "uma semente de rememoração". A vó de Lu se constitui então como uma griote, ao desempenhar, na tradição oral, o vínculo entre o passado e o presente, assegurando a perenidade da cultura angolana. A estrutura do fragmento do romance revela a permanente preocupação do escritor angolano com a criação literária:

Do século XX à contemporaneidade muito se produziu e continua a ser produzido, desde a clara e indisfarçada dependência estética do discurso da colônia até a escrita revitalizada, hibridizada, construída por meio de estórias populares, os misossos, expressas por contadores orais, os griots da tradição (FEITOSA, 2016, p. 65).

Para a autora, escritores como Pepetela e Luandino Vieira "galgaram os degraus do redimensionamento da literatura angolana". Segundo Ana Mafalda Leite (2010), por meio de Luandino, os textos da literatura africana em língua portuguesa decorrem de um processo de hibridização em que têm lugar as tradições orais e a escrita, deixando transparecer a harmonia entre o novo e o velho, de maneira que, no espaço do texto, coexistem a escrita e a oralidade.

O entrelaçamento do moderno com o tradicional é percebido em ambas as histórias, narradas de maneira simultânea por narradores/vozes diferentes que submetem seus pontos de vista ao julgamento da história oficial. Enquanto a rainha Lueji é situada em um contexto de rompimento com a tradição, Lu tenta resgatar o que se perdeu dela para configurar suas identidades em um novo contexto. Lu é mestiça e percebia o mundo então como mestiço ao ver que os mitos europeus eram reproduzidos em sua cidade sem nenhum questionamento, como se fossem próprios de sua cultura. Para ela o mundo se mestiçara (PEPETELA, 2015).

$\mathrm{O}$ conhecimento mítico entra em disputa com a história oficial, uma vez que, de acordo com Yi-Fu Tuan em Espaço e lugar: a perspectiva da experiência (2013), a narrativa mítica não é uma propriedade do passado, uma vez que o "conhecimento humano parece limitado". As lacunas que carecem de ser preenchidas pela história são preenchidas pelo saber mitológico. Tuan, ao se referir ao "espaço mítico como componente espacial", percebe que "a visão de mundo" é uma forma de as pessoas organizarem, auxiliando na compreensão do "meio ambiente". Para Benjamin Abdala Júnior, em De voos e ilhas: literatura e comunitarismo (2007), o mito é uma narrativa que aponta para o futuro, uma forma de o homem reclamar sua história e que pode se constituir como base simbólica para momentos em que conflitos de paradigmas culturais de instauram na realidade.

Nesta perspectiva, vale ressaltar o diálogo que a personagem $\mathrm{Lu}$ tem com o personagem Herculano, um historiador. Como já citado, Lu recorre à história/mito de Lueji para escrever um espetáculo performático a ser apresentado pelo Grupo de Dança Kukina, do qual faz parte. Tal pretensão a leva a uma angústia e a uma identificação gradativa com a personagem históricomitológica, da qual se reconhece como descendente, fato que a impulsiona a pesquisar sobre.

Ao submeter seus escritos ao julgamento de Herculano, se acirra uma discussão entre os dois sobre a veracidade histórica que alimenta o espetáculo. Ele põe em questão as contradições presentes nas narrativas orais que se ocupam em recontar as versões contraditórias ligadas a questões ideológicas. Ao defender o seu ponto de vista acerca do roteiro do bailado, afirma:

- É certo que há versões contraditórias. Contudo na tradição oral,cada grupo deforma uma versão em função de seus interesses mais ou menos imediatos, isto é, a versão tradicional é sempre ideológica, justifica ou o poder que se tem ou o poder que se quer obter. Ou o porquê de se ter perdido o poder. Depurar a versão da ideologia que nela está presente, eis o trabalho da ciência Histórica. E isso só se pode fazer comparando as diferentes versões e situando cada uma no seu contexto histórico (PEPETELA, 2015, p. 357).

Enquanto para ele o ponto de vista científico se constitui do que tem de comum a todas estas versões, ela refuta e afirma que a narrativa de Lueji e do Império lunda se configura uma interpretação possível e válida sobre todas as versões, tanto orais quanto escritas, já existentes. Instaura-se aí uma reflexão a respeito da relação entre mito e história. Esta, como agente fossilizador, de acordo com Halbwachs (2003) e Nora (1992), ao descartar determinados pontos de vista, não deixa de ser uma criação ideológica que enterra culturas e povos que não possuem tanta relevância. A Ciência histórica só se baseia em rastros. O músico Afonso Mabiala fala pelo coletivo da memória: 
O que realmente passou naqueles tempos tão antigos, é mentira, ninguém vai saber. Por muitas metodologias científicas que se usem. O que importa é o que as pessoas imaginaram, criaram, a partir dos fatos definitivamente enterrados na areia. Nos interessa a imaginação, a poesia, a mensagem que os intelectuais da época sintetizaram no mito. E esse mito, por isso, pode ser mudado à vontade, é a liberdade da imaginação, da criação artística. E abaixo a tirania dos dogmas! Sobretudo os pretensamente históricos. Tu, Herculano, dizes que não é lógico que fizessem assim ou assado. Não é lógico dentro da tua lógica de hoje. Que sabes sobre a lógica daquela época? (PEPETELA, 2015, p. 359).

Ao buscar o elo entre o passado pré-colonial e o sonho utópico de liberdade minado pela guerra civil, Pepetela coloca em cena duas histórias, aparentemente distantes no espaço/tempo, mas interligadas pela ação transformadora da memória. A ambição da memória à fidelidade se perde na relação que ela estabelece com a imaginação e, quando se coloca em oposição à História, constituem um par de antinomias com poucas probabilidades de convergência. Os conflitos produzidos nestes entremeios se dão por dois motivos: (1) a memória é o nosso único meio de ressignificar o passado; (2) a imaginação está isenta de julgamentos que pretendem estabelecer o lugar da verdade, pois não se apoia no "real", e sim na ficção (RICOUER, 2007). Ao lançar mão destes recursos, transitamos entre Lunda e Luanda, num movimento contrário ao da História cientificista.

\section{Considerações finais}

A intenção deste artigo é o de contribuir para os estudos da Literatura angolana de expressão portuguesa a partir de um olhar que valorize a memória como um aspecto de forte relevância para a reinterpretação do passado. Lueji, o nascimento de um império nos abre um percurso para a compreensão dos conflitos vividos por sujeitos deslocados dentro do seu próprio contexto social, cultural e histórico. Isto se evidencia pelo fato de que o romance é produzido no momento em que as incertezas do futuro ainda se encontram latentes em Angola.

Sendo um dos escritores mais profícuos na literatura angolana, Pepetela aguça o nosso olhar crítico e coloca o seu leitor, inclusive o mais desprevenido, no cerne dos problemas vividos, não só por esta nação, mas também por muitas outras ex-colônias que se tornaram independentes já na segunda metade do século XX. Dentre os principais problemas encontra-se o de reafirmação de identidades, já plurais, por meio de um passado escamoteado pela empresa colonial, neste espaço tão plural em que a nação já se encontra.
A chegada do novo milênio figura no imaginário como uma nova era, lugar em que os desafios de outrora têm que ser encarados na perspectiva de construir o futuro no presente dado, contudo sem esquecer o passado. Não mais como a mesma intensidade do sonho utópico da independência, de certa forma ingênuo; não mais com a nostalgia de tempos imemoriáveis; mas com o mesmo desejo de Lueji e de Lu: o de reinterpretar o passado num presente já modificado pela espera do futuro. Tais personagens, de forma contínua e ativa, trabalham arduamente, mesmo apesar de todos os obstáculos encontrados nos seus contextos.

Dar voz à memória implica em oferecer uma escuta às histórias das minorias, que são preservadas em formações sociais mais íntimas como a família, grupo de amigos que nunca deixaram de ritualizar o passado vivo em contações de estórias, gestos, hábitos, costumes cotidianos, fortalecendo assim o sentimento de pertencimento a uma comunidade e, consequentemente, o sentimento de identidade (POLLAK, 1992). Nesta esteira, a Literatura se coloca, ao mesmo tempo, na condição de "porta-voz" e de escuta de grupos étnicos que, temendo o esquecimento, encontram nela forte aliada na preservação e no conhecimento de uma história, supostamente, apagada.

O esquecimento deste passado esfacela e desconfigura a identidade almejada para estabelecer o lugar de Angola no mundo (CHAVES, 2005). Engajados no projeto de reconfiguração da identidade angolana, autores como Pepetela aproximam a escrita literária da oralidade, utilizando a língua portuguesa como uma contra-arma àquela que os colonizadores impuseram.

\section{Referências}

ABDALA JR. Benjamin. De voos e ilhas: literatura e comunitarismo. Cotia, SP: Ateliê Editorial, 2007.

CHAVES, Rita. Angola e Moçambique: experiência colonial e territórios literários. Cotia, SP: Ateliê Editorial, 2005.

CHAVES, Rita; MACÊDO, Tânia. Literaturas de Lingua Portuguesa: marcos e marcas. São Paulo: Arte e Ciência, 2007.

FEITOSA, Márcia Manir Miguel. Memória, tradição e escrita em Agualusa: a Angola contemporânea em $O$ vendedor de passados. In: Revista Interdisciplinar em Cultura e Sociedade (RICS), São Luís, v. 2, n. 2, p. 63-79, jul./dez. 2016.

HALBWALCHS, Maurice. A memória coletiva. Tradução Beatriz Sidou. São Paulo: Centauro, 2003.

LARANJEIRA, Pires. Literatura Calibanesca. Porto: Afrontamento, 1985.

LEITE, Ana Mafalda. Empréstimos da Oralidade na Produção e Crítica Literárias Africanas. Disponível em: <http://www. ueangola.com/index.php/criticas-e-ensaios $>$. Acesso em: 25 set. 2016.

OLIVEIRA, Lívia de. O sentido de lugar. In: MARANDOLA JR., Eduardo; HOLZER, Werther; OLIVEIRA, Lívia de. Qual 
o espaço do lugar: Geografia, epistemologia, fenomenologia. São Paulo: Perspectiva, 2014.

PADILHA, Laura Cavalcante. Entre voz e letra: o lugar da ancestralidade na ficção angolana do século XX. Niterói, RJ: EDUFF, 1995.

PEPETELA. Lueji, o nascimento de um império. São Paulo: Leya, 2015.

POLLAK, Michael. Memória, esquecimento, silêncio. Estudos Históricos, Rio de Janeiro, v. 2, n. 3, p. 3-15, 1989.

Memória e identidade social. Estudos Históricos, Rio de Janeiro, v. 5, n. 10, p. 200-212, 1992.

RICOUER, Paul. Tempo e narrativa. Tradução Constança Marcondes Cesar. Campinas, SP: Papirua 1994. Tomo 1.

A memória, a história, o esquecimento. Tradução Alain

François et al. Campinas, SP: Editora da UNICAMP, 2007.
SANTOS, Myrian Sepúlveda dos. Memória coletiva e teoria social. São Paulo: Annablume: 2003.

TUAN, Yi-FU. Espaço e lugar: a perspectiva da experiência. Tradução Lívia Oliveira. São Paulo: DIFEL, 2013.

Autores:

FÁBIO HENRIQUE NovaIs DE MESQUITA (correspondente)

Universidade Federal do Maranhão.

São Luís, MA, Brasil

fabiomesquitaletras@gmail.com

MÁRCIA MANIR Miguel FeITOSA

Universidade Federal do Maranhão.

São Luís, MA, Brasil

marciamanir@hotmail.com

Recebido: $27 / 04 / 2017$

Aprovado: 30/07/2017 